\title{
First Case Report of Human Granulocytic Anaplasmosis In Mexico With Serological and Molecular Evidence
}

\author{
Carolina G Sosa-Gutierrez ${ }^{* 1,2}$, M Almudena Cervantes Castillo ${ }^{3}$ \\ ${ }^{1}$ Área de Medicina Veterinaria y Zootecnia, Universidad Autónoma del Estado de Hidalgo, México \\ ${ }^{2}$ Laboratorio Nacional de Genómica y Salud, Singuilucan, México \\ ${ }^{3}$ Departamento de Infectología, Hospital Infantil de México Federico Gómez, Mexico
}

Received: April 06, 2018; Published: April 17, 2018

*Corresponding author: Carolina G Sosa Gutierrez, Área de Medicina Veterinaria y Zootecnia, Universidad Autónoma del Estado de Hidalgo, Tulancingo de Bravo, Laboratorio Nacional de Genómica y Salud. Singuilucan, Hidalgo, México, Tel: 52551780 8062; Email: carolina_sosa@uaeh.edu.mx;

\begin{abstract}
Human Granulocytic Anaplasmosis in a tick-borne rickettsial disease casused by Anaplasma phagocytophilum, and transmited by Ixodes scapularis tick. Since the first recognition in 1990 in United States, theres no evidence of human cases in Mexico dispited the vector and reservoirs are reported already. We report the first case of Human Granulocytic Anaplasmosis in Mexico with serological and molecular evidence.
\end{abstract}

Keywords: Anaplasma phagocytophilum; human; Ticks

\section{Introduction}

Human Granulocytic Anaplasmosis (HGA) is an emerging tickborne rickettsial disease, caused by Anaplasma phagocytophilum; a Gram-negative intracelular bacteria. The first recognition of A. phagocytophilum was 1990 in United States [1]. Seroepidemiological rates in endemic areas are as hight as $15-36 \%$ [2]. A. phagocytophilum is transmited by Ixodes scapularis ticks, as the principal competent vector, and Peromyscus leucopus mice as a major host reservoir in the wild cycle. Until now theres no evidence of mexican cases have been previously reported dispited the vector and reservoirs are reported in Mexico [3,4]. We present the first case of HGA acquired in a rural area from Estado de Mexico, Mexico.

\section{Cases Report}

A 5-year-old female, presented in September, 2017 to the emergency department of a tertiary care hospital in Mexico City, with a 2-day history of fever $\left(38.0^{\circ} \mathrm{C}\right)$, frontal headache, productive cough, nausea and vomiting, followed by upper limb weakness that began one day prior to the admission. She lived in Estado de Mexico, in a suburban area, with her parents and one sibling. The parents denied recent travel and sick contacts. They didn't own pets, but she had contact with a dog with ticks. Vital signs in the emergency department were notable for a heart reat of 150 beats/min and respiratory rate of 30 breaths/min, with normal temperature. The patient was alert and oriented. The physical exam revealed intercostal retractions and bibasilar crackles, and the neurologic examination was notable for bilateral upper limb weakness (proximal 2/5 MRC, distal 1/5 MRC) and disminished stretch reflexes in the left arm. The speech was intact and fundi normal. There was no nuchal rigidity and Kernig's sign was absent.

Initial laboratory study results were notable for a white blood cell count of $16.2 \times 10^{3}$ cells $/ \mathrm{mm}^{3}$ with $66 \%$ neutrophils and $21 \%$ lymphocites, hemoglobin of $14.6 \mathrm{~g} / \mathrm{dL}$, platelets of 354000 cells/ $\mathrm{mm}^{3}$, creatine kinase of $102 \mathrm{U} / \mathrm{L}$. Liver and renal function tests were within normal limits. Chest radiography revealed interstitial infiltrates predominantly in the right hemithorax. Head CT was normal. Lumbar puncture was performed and cerebrospinal fluid analysis revealed a white blood cell count of 20 cells $/ \mathrm{mm}^{3}$ with predominantly mononuclear cells (81\%), red blood cell count of 286 cells $/ \mathrm{mm}^{3}$, protein $71 \mathrm{mg} / \mathrm{dL}$, glucose $78 \mathrm{mg} / \mathrm{dL}$. Gram stain and CSF culture were negative. The patient was hospitalized and antibiotic treatment with cefotaxime was initiated. A few hours following admission, her respiratory condition deteriorated and or tracheal intubation was performed for invasive mechanical ventilation. A presumptive diagnosis of acute polyradiculoneuropathy was rendered and five sessions of plasmapheresis were performed without clinical improvement.

PCR testing of CSF was negative for enterovirus and VSH infection. Oligoclonal band testing in CSF revealed multiple restriction bands that were also present in serum, and myelin 
basic protein was negative. Electroencephalography was normal. T-2 weighted Magneitc Resonance Imaging (MRI) showed a diffuse hyper intense signal within spinal cord from C4 to T4, without contrast enhancement. A nerve conduction velocity test revealed axonal changes and conduction block in the tibial and peroneal nerves. Electromyography showed changes compatible with bilateral L2-L4 radiculopathy. One week after admission, general muscular weakness had progressed to the point that she was unable to move her upper limbs (0/5 MRC, bilateral) and her legs were also affected (proximal 3/5 MRC, distal 2/5 MRC). A course of intravenous immunoglobulin at $2 \mathrm{gr} / \mathrm{kg}$ dose was administered. An elective tracheostomy was performed because mechanical ventilation was still required due to respiratory muscle weakness.

Given the unfavorable clinical course despite therapy for acute polyradiculoneuropathy. A written informed consent was obtained to their parents. Were performed in serum and CSF to Western Blott and ELISA for Borrelia burgdorferi, and IFA test (IgM and IgG) for Rickettsia rickettsii, Anaplasma phagocytophilum, Ehrlichia chaffeensis and Borrelia burgdorferi; and also Polymerase Chain Reaction to DNA extracted by white cells blood was teste by Rickettsia rickettsii, Anaplasma phagocytophilum, Ehrlichia chaffeensis and Borrelia burgdorferi for Groel gene as describe [5]. The titter was positive to A. phagocytophilum (1:160), and negative for the rest. We run PCR products, finding a positive product for A. phagocytophilum (No. Accession KR872895), following the WHO (2008) recommendation by confirmed case. Treatment with doxycycline was started, and gradual improvement of lower limb strength was observed over one week, allowing for ambulation, although upper limb plegia persisted. Improvement in respiratory muscle weakness has allowed for progressive weaning of mechanical ventilation, although she still needs intermittent respiratory support with positive pressure through tracheostomy. A repeat lumbar puncture was performed after 5 weeks of treatment with doxycycline and PCR assay of CSF and blood was negative for Anaplasma phagocytophilum. Doxycycline was stopped after 37 days of treatment.

\section{Discussion}

HGA is a tick-borne rickettsial disease caused by $A$ phagocytophilum, and has previously been described in many parts of the United States [2], Canada [6], Europe [7] and Asia [8], but curiously it has not been described in Mexico, even with the reported of their competents vector [3] and reservoirs [4] involving in wild and domestic cycle. Patients presenting clinical manifestation like fever, leukopenia/lymphopenia, thrombocytopenia and increased serum transaminases during the month of March to October, when the pick of tick activities should included in the differential diagnosis such as HGA and other rickettsial diseases [2].

Approximately one-half of symptomatic patients require hopitalization, and 5-7\% require intensive care [2]. If the clinical signs and manifestation are presents, but hasnt historical or epidemiological exposure for tick, should not exclude the diagnosis $[7,9]$. Few patients report tick exposure one or two weeks before the onset of infection. Diagnostic by PCR could be a sensitive tool and are recomendet until 14 days post infection $[2,10]$. In this case, therefore documentation of infection in a dog, which often is in contact with ticks than humans, should promptly veterinary to warn owners of an increased risk of tick-borne disease. Expasion of tick population can introduced rickettsial agents to new geographical areas, and novel rickettsiae and relationships between vectorhost-human will increase [9]. Locally reproducing populations of I. scapularis are reported in Estado de Mexico, and it is apparent the first case of locally transmitted of HGA [11]. The present case document the risk for a diseases not previously report to occur in Mexico. From now, we need more epidemiological data, diagnostics tools, and training in health personnel to identified these new cases.

\section{References}

1. Chen SM, Dumler JS, Bakken JS, Walker DH (1994) Identification of a granulocytotropic Ehrlichia species as the etiologic agent of human disease. J Clin Microbiol 32(3): 589-595.

2. Dumler JS, Choi KS, GarciaGarcia JC, Barat NS, Scorpio DG, et al. (2005) Human Granulocytic Anaplasmosis and Anaplasma phagocytophilum. Emerging Infectious Diseases 11(12): 18281834.

3. Vargas Sandoval M, Priego Santander AG, Larrazábal A, SosaGutierrez CG LaraChávez MB, et al. (2014) Potential species distribution and richness of Ixodidae ticks associated with wild vertebrates from Michoacán, Mexico. J Geo Inf Sys 6(5): 2014.

4. Sosa Gutierrez CG, Vargas M, Torres J, GordilloPérez MG (2014) Tickborne rickettsial pathogens in rodents from Mexico. J Biome Sci Eng $7(11): 884889$.

5. Graf PC, Chretien JP, Ung L, Gaydos JC, Richards AL (2008) Prevalence of seropositivity to Spotted fever group Rickettsiae and Anaplasma phagocytophilum in a large, demographically diverse US simple. Clinical Infectious Diseases 46(1): 70-77.

6. Parkins MD, Church DL, Yan JX, Gregson DB (2009) Human granulocytic anaplasmosis: first reported case in Canada. Can J Infect Dis Med Microbiol 20(3): e100-e102.

7. Koebel C, Kern A, Edouard S, Thu HA, Celestin N, et al. (2012) Human granulocytic anaplasmosis in easter France: clinical presentation and laboratory diagnosis. Diagnostic Microbiology and Infectious Diseases 72: 214218.

8. Zhang L, Liu H, Xu B, Zhang Z, Jin Y, et al. (2014) Rural residents in China are at increased risk of exposure to tickborne pathogens Anaplasma phagocytophilum and Ehrlichia chaffeensis. BioMed Reseach International p. 11.

9. Nicholson WL, Allen KE, Mcquiston JH, Breitschwerdt EB, Little SE (2010) the increasing recognition of rickettsial pathogens in dogs and people. Trends in Parasitology 26(4): 205212.

10. Azad AF (2007) Pathogenic Rickettsiae as bioterrorism agents. Clinical Infectious Diseases 45: S5255.

11. Eshoo MW, Crowder CD, Li H, Matthews HE, Meng S, et al. (2010) Detection and Identification of Ehrlichia spececies in blood by use PCR and electrospray ionization Mass Spectrometry. J Clin Microbiol 48(2): 472478. 
(c) (i) This work is licensed under Creative BY Commons Attribution 4.0 License Submission Link: https://biomedres.us/submit-manuscript.php

$\begin{array}{ll}\text { BIOMEDICAL } & \text { Assets of Publishing with us } \\ \text { RESERCHES } & \text { Global archiving of articles } \\ \text { - Immediate, unrestricted online access } & \text { Rigorous Peer Review Process } \\ & \text { - Authors Retain Copyrights } \\ \end{array}$

